\title{
Role of exogenous 24-epibrassinolide in enhancing the salt tolerance of wheat seedlings
}

\author{
Yuanjie Dong ${ }^{1}$, Wanwan Wang ${ }^{1}$, Guoqing $\mathrm{Hu}^{1}$, Weifeng Chen ${ }^{1}$, Yupng Zhuge ${ }^{1}$, Zhenlin \\ $\mathrm{Wang}^{2}$, Ming Rong $\mathrm{He}^{2 *}$ \\ ${ }^{1}$ College of Resources and Environment, Shandong Agricultural University, Tai'An, 271018, P.R. China. ${ }^{2}$ Co- \\ llege of Agronomic Sciences, Shandong Agricultural University, Tai'an 271018, People's Republic of China. \\ *Corresponding author: mrhe@sdau.edu.cn
}

\begin{abstract}
To understand the functions of exogenous 24-Epibrassinolide (EBR) in enhancing the salt tolerance of wheat ( $T$. aestivum L.) seedlings to salt stress, a hydroponic experiment was performed to investigate the effects of EBR on chlorophylls, root activity, $\mathrm{H}^{+}$-ATPase, malondialdehyde (MDA), electrolyte leakage, free proline, soluble protein, reactive oxygen species (ROS), antioxidant enzymes and minerals content in wheat plants subjected to non-stress conditions or salt stress $(120 \mathrm{mM} \mathrm{NaCl})$ with foliar application of EBR $(1,10$ and $100 \mathrm{nM})$. Results showed that spray of low concentrations EBR $(1$ and $10 \mathrm{nM})$ under non-stress conditions could promote wheat plant growth. $120 \mathrm{mM} \mathrm{NaCl}$ induced osmotic stress, oxidative stress and imbalance in mineral nutrients absorption. However, EBR enhanced the ability of resistance to osmotic stress by increasing free proline and soluble protein content, and enhanced the ability of resistance to oxidative stress by increasing antioxidant enzymes activities. As a result of increase of chlorophyll content, root activity and $\mathrm{H}^{+}$-ATPase activity, the inhibition of $\mathrm{K}, \mathrm{Ca}, \mathrm{Mg}, \mathrm{Fe}$ and $\mathrm{Zn}$ uptake was ameliorated and consequently, decline in plant growth induced by $\mathrm{NaCl}$ stress was alleviated. Based on these results, we conclude that EBR had a positive role in regulating wheat growth and development under salt stress, and spray of $10 \mathrm{nM}$ EBR had the most significant alleviating effect against $\mathrm{NaCl}$ toxicity.
\end{abstract}

Keywords: Salt stress, wheat, EBR, antioxidative systems, ion accumulation

\section{Introduction}

Salinity stress is one of the most serious abiotic stress factors limiting crop productivity, and it is a menace for the cultivation of plants across the globe and causes drastic changes in plant growth and development (Roy et al., 2014; Hussain et al., 2016). NaCl- specific damage is associated with the accumulation of $\mathrm{Na}^{+}$in leaf tissues and results in necrosis of older leaves, starting at the tips and margins and working back through the leaf. Growth and yield reductions occur as a result of the shortening of the lifetime of individual 
leaves, thus reducing net productivity and crop yield. Salt stress causes a number of changes in plant metabolism. Of them, ion toxicity, osmotic stress and production of ROS are most prominent (Tian et al., 2015). Salinity also induces water deficit even in well watered soils by decreasing the osmotic potential of soil solutes, thus making it difficult for roots to extract water from their surrounding media. ROS are highly reactive and in the absence of any protective mechanism they can seriously cripple normal metabolism through oxidative damage to lipids, proteins and nucleic acids (Athar et al., 2008), which results in premature leaf senescence and loss of photosynthetic efficiency leading to reduced carbon assimilation and ultimately crop yield. To alleviate these oxidative effects, plants generate different kinds of antioxidants such as superoxide dismutase (SOD), catalase (CAT) and peroxidase (POD) (Tian et al., 2015). Salinity causes the accumulation of low molecular weight compounds called compatible solutes such as proline and glycine betaine (Chen et al., 2007). High salinity adversely affects growth, physiology and productivity by increasing ion toxicity, and decreasing protein synthesis and lipid metabolism (Geissler et al., 2009). In addition, further investigations regarding the approaches to alleviating salinity toxicity are needed.

Brassinosteroids (BRs) play a prominent role in various physiological processes in plants, like cell division and expansion, xylem differentiation, stem elongation and root growth (Choudhary et al., 2012, Zheng et al., 2016). Moreover, BRs are also reported to have an ameliorative effect on plants subjected to environmental stress such as drought stress (Hua et al., 2013), cold stress (Hu et al., 2010), heat stress (Zhang et al., 2013) and heavy metals (Hayat et al., 2010, Fariduddin et al., 2015). Karlidag et al. (2011) demonstrated that BRs can mitigate the adverse effects of salt stress on stomatal conductance, membrane permeability, and leaf water content, ionic composition in salt stressed strawberry, and Derevyanchuk et al. (2015) also indicated that BRs can stimulate total respiration rate in Arabidopsis thaliana leaf, particularly alternative respiratory pathway, under salt stress conditions. BR-enhanced stress tolerance is associated with the regulation of ROS metabolism and the increase in the antioxidant enzyme activity, as well as with elevated content of ascorbic acid, glutathione, carotenoids, abscisic acid, etc. (Mazorra Morales et al., 2014). Fariduddin et al. (2015) suggested that BRs affect the synthesis of proteins or enzymes by involving the specific gene expression that improves the overall metabolic activities of plants. Moreover, Ali et al. (2008) demonstrated that BRs also modified the plasma membrane, increased the nutrient uptake and assimilation and facilitated the translocation of photosynthates to the sink, besides improving metabolic activities, under stress conditions. All of these results indicated the importance of BRs in protection against stress-induced deleterious effects. Although some studies demonstrated that BRs could alleviate salinity toxicity (Sharma et al., 2013; Derevyanchuk et al., 2015), the mechanisms of EBR action on salt tolerance in plants are still far from being completely understood.

Wheat is an important cereal crop, and it is a moderately salt-tolerant crop (Tian et al., 2015). The growth and grain yield of wheat are significantly affected by soil salinity. Recently, wheat salt-responsive proteins or the molecular mechanisms of salt tolerance in wheat ( $\mathrm{Li}$ et al., 2013) were evidenced. Many studies demonstrated that BRs could enhance salt tolerance in multiple plants, such as rice (Sharma et al., 2013), strawberry (Karlidag et al., 2011) and Arabidopsis thaliana (Derevyanchuk et al., 2015), but limited information is available on the role of brassinosteroids (BRs) in response of wheat plants to salt stress. Therefore, this experiment focuses on the effect of the exogenous application of 24-EBR as a foliar spray on the plant growth, some physiological parameters and chemical content of wheat plants under saline conditions, and determines the mechanism of the application of exogenous 24-EBR could alleviate salinity toxicity and increase salt-tolerance of wheat plants. 


\section{Materials and Methods}

\subsection{Plant material and culture conditions}

Seeds of common wheat (T. aestivum L. cv. Shannong 22) were surface sterilized with $10 \%(\mathrm{v} / \mathrm{v})$ sodium hypochlorite solution for $10 \mathrm{~min}$, then vigorously rinsed with distilled water. Sterilized seeds were sown in plug tray and arranged in FPG-300C-30D illumination incubator $\left(25 / 20^{\circ} \mathrm{C}\right.$; day/night, light intensity $150 \mathrm{\mu mol}$ $\mathrm{m}^{-2} \mathrm{~s}^{-1}, 14 \mathrm{~h}$ photoperiod, $60 \%$ relative humidity). Two weeks after sowing, two fully expanded leaves were maintained, plants at the same growth stage were selected and transplanted to glass containers $\left(6.0 \times 3.5 \times 10.0 \mathrm{~cm}^{3}\right)$ filled with Hoagland solution. Plants were sprayed with water or with EBR. The experimental design is given as follows: (1) $0 \mathrm{mM} \mathrm{NaCl}+0 \mathrm{nM} \mathrm{EBR}$ (CK); (2) $120 \mathrm{mM}$ $\mathrm{NaCl}+0 \mathrm{nM}$ EBR (NaCl); (3) $0 \mathrm{mM} \mathrm{NaCl}+100 \mathrm{nM}$ EBR (EBR1); (4) $0 \mathrm{mM} \mathrm{NaCl}+10 \mathrm{nM}$ EBR (EBR2); (5) $0 \mathrm{mM} \mathrm{NaCl}+1 \mathrm{nM} \mathrm{EBR} \mathrm{(EBR3);} \mathrm{(6)} 120 \mathrm{mM} \mathrm{NaCl}$ + $100 \mathrm{nM}$ EBR (NaCl+EBR1); (7) $120 \mathrm{mM} \mathrm{NaCl}+10$ nM EBR (NaCl+EBR2); (8) $120 \mathrm{mM} \mathrm{NaCl}+1 \mathrm{nM} \mathrm{EBR}$ $(\mathrm{NaCl}+\mathrm{EBR} 3)$. The nutrient solution was adjusted to $\mathrm{pH}$ 6.5-6.8. The treatment solution was changed daily to maintain constant $\mathrm{NaCl}$ concentration. The plants were sampled at $15 \mathrm{~d}$ after treatment.

\subsection{Determination of plant growth and relative water content}

After harvest, shoots and roots of wheat seedlings were separated and carefully rinsed with distilled water and blot dried with tissue papers before fresh weight (FW) was recorded. Plant samples were oven-dried at $80{ }^{\circ} \mathrm{C}$ to a constant mass before the dry weight (DW) was recorded and relative water content (RWC) was calculated as follow:

$\mathrm{RWC}(\%)=(\mathrm{FW}-\mathrm{DW}) / \mathrm{FW} \times 100$.

\subsection{Determination of chlorophyll content}

The chlorophyll content was determined according to the method of Song et al. (2016). Fresh wheat leaf $(0.5 \mathrm{~g})$ was extracted in $2 \mathrm{~mL} 95 \%$ ethanol for $24 \mathrm{~h}$ in the dark, and the extracted solution was analyzed. The amounts of chlorophyll a, b and carotenoid were determined using a spectrophotometer (SHIMADZU UV-2450, Kyoto, Japan), by reading the absorbance at 665,649 and $470 \mathrm{~nm}$ respectively. The chlorophyll content results are expressed as unit's mg per gram-fresh weight ( $\left.\mathrm{mg} \mathrm{g}^{-1} \mathrm{FW}\right)$.

\subsection{Determination of root activity}

The root activity was expressed in the amount of triphenyl formazan (TTF) deoxidized by triphenyltetrazolium chloride (TTC), as described by Duncan and Widholm (2004) with some modifications. Briefly, roots were washed thoroughly with distilled water and finally with de-ionized water and cut into small pieces. Root samples ( $0.5 \mathrm{~g}$ each) were placed into test tubes, $5 \mathrm{ml} 0.4 \%$ TTC and $5 \mathrm{ml} 1 / 15 \mathrm{mM}$ phosphatic buffer solution ( $\mathrm{pH}$ 7.0) were added to each tube and reacted for $2 \mathrm{~h}$ at $37^{\circ} \mathrm{C}$. Then $2 \mathrm{ml}$ of $1 \mathrm{M} \mathrm{H}_{2} \mathrm{SO}_{4}$ was added to stop the reaction. The TTF was extracted by $95 \%$ ethanol for $24 \mathrm{~h}$ till the root fade the red color.

\subsection{Determination of $H^{+}$-ATPase in PMs}

A membrane fraction enriched in plasma membrane vesicles was prepared as described by Song et al. (2016) with minor modifications. Excised roots were homogenized $(1 / 2, w / v)$ with a mortar and pestle in ice containing: $25 \mathrm{mM}$ HEPES-Tris (pH 7.2), $250 \mathrm{mM}$ mannitol, $5 \mathrm{mM}$ EDTA, $1 \mathrm{mM}$ DTT and $1.5 \%(\mathrm{w} / \mathrm{v})$ PVP. The whole isolation procedure was carried out at $4{ }^{\circ} \mathrm{C}$. The homogenate was filtered through four-layer cheesecloth and centrifuged at $560 \times g$ for $12 \mathrm{~min}$, then the supernatant was centrifuged at $10,000 \times g$ for 15 
min, and the obtained supernatant was then centrifuged at $60,000 \times g$ for $30 \mathrm{~min}$ to yield a crude membrane fraction. The resulted pellet was re-suspended with 1 $\mathrm{ml}$ in a gradient buffer containing: $20 \mathrm{mM}$ HEPES-Tris (pH 7.5), 5 mM EDTA, and 0.5 mM EGTA. The supernatant was layered on top of a step gradient consisting of $1 \mathrm{ml}$ of 45,33 and $15 \%(\mathrm{w} / \mathrm{w})$ sucrose, respectively, and then centrifuged for $2 \mathrm{~h}$ at $70,000 \times g$.

ATP hydrolysis assays were performed as described by Wang et al. (2016). $0.5 \mathrm{ml}$ of the reaction medium containing: $36 \mathrm{mM}$ Tris-Mes (pH 6.5), $30 \mathrm{mM}$ ATP- $\mathrm{Na}_{2}, 3$ $\mathrm{mM} \mathrm{MgSO}{ }_{4}, 1 \mathrm{mM} \mathrm{NaN}_{3}, 50 \mathrm{mM} \mathrm{KNO}_{3}, 1 \mathrm{mM} \mathrm{Na}_{2}-$ $\mathrm{MoO}_{4}, 0.02 \%(\mathrm{v} / \mathrm{v})$ Triton X-100, in the presence or absence of $2.5 \mathrm{mM} \mathrm{Na}_{3} \mathrm{VO}_{4}$. The reaction was started by adding $50 \mathrm{ml}$ PM vesicles. After $30 \mathrm{~min}$ incubation at 37 ${ }^{\circ} \mathrm{C}$, the reaction was quenched by the addition of $55 \%$ (w/v) TCA. The $\mathrm{H}^{+}$-ATPase activity was determined by measuring the release of $\mathrm{Pi}$ (Wang et al., 2016).

\subsection{Determination of lipid peroxidation and membrane Permeability}

Lipid peroxidation was evaluated by measuring malondialdehyde content (MDA), as described by Heath and Dong et al. (2015). About $100 \mathrm{mg}$ of the frozen plant materials (roots and leaves) was ground in $1.5 \mathrm{ml}$ of $0.1 \%$ trichloroacetic acid (TCA) and centrifuged. An aliquot of $0.5 \mathrm{ml}$ of the supernatant was reacted with $0.5 \mathrm{ml} 20 \%$ TCA containing $0.5 \%$ thiobarbituric acid (TBA) at $90{ }^{\circ} \mathrm{C}$ for $20 \mathrm{~min}$, then cooled in an ice bath. The resulting mixture was centrifuged at $12,000 \mathrm{rpm}$ for $10 \mathrm{~min}$ and the absorbance of the supernatant was measured at $532 \mathrm{~nm}$. Measurements were corrected for unspecific turbidity by subtracting the absorbance at $600 \mathrm{~nm}$. The amount of MDA was expressed as nmol g-1 $\mathrm{FW}$.

Wheat leaves were harvested and cut into $3-4 \mathrm{~mm}$ pieces. The leaves were washed in deionized water to remove surface-adhered electrolytes and then were placed in Petri dishes with $15 \mathrm{ml}$ of deionized water at $25^{\circ} \mathrm{C}$ for $3 \mathrm{~h}$. Electrical conductivity in the bath solution was determined $\left(\mathrm{EC}_{1}\right)$. Then, the samples were heated at $100{ }^{\circ} \mathrm{C}$ for $2 \mathrm{~h}$ and conductivity of the bath solution was read again $\left(\mathrm{EC}_{2}\right)$. Relative ion leakage $(\%)=\mathrm{EC}_{1} / \mathrm{EC}_{2} \times 100$

\subsection{Determination of proline and protein content}

Proline concentration was determined using the method of Tian et al. (2015). After extraction at room temperature with $3 \% 5$-sulfosalicylic acid solution, the proline content was determined from a standard curve and calculated on fresh weight basis. Soluble protein content was determined according to Tian et al. (2015) using the Coomassie brilliant blue G-250 reagent with bovine serum albumin (BSA) as standard.

\subsection{Determination of $\mathrm{O}_{2}$ generation rate and $\mathrm{H}_{2} \mathrm{O}_{2}$} concentration

Superoxide anion radical generation rate was measured by the sulfanilamide method (Tian et al., 2015). Samples were homogenized in $0.05 \mathrm{M}$ phosphate buffer ( $\mathrm{pH}$ 7.8) by grinding with a mortar and pestle under chilled condition. The homogenate was filtered through four-layers muslin cloth and centrifuged at $12,000 \times \mathrm{g}$ for $10 \mathrm{~min}$ at $4{ }^{\circ} \mathrm{C}$. The absorbance was measured at $530 \mathrm{~nm}$, and $\mathrm{O}_{2}{ }^{--}$generation rate was calculated from a standard curve of $\mathrm{NaNO}_{2}$ reagent.

For determination of $\mathrm{H}_{2} \mathrm{O}_{2}$ content, $1 \mathrm{~g}$ fresh leaves, roots were homogenized in $2 \mathrm{~cm}^{3}$ ice-cold acetone centrifuged at $4000 \mathrm{~g}$ for $15 \mathrm{~min}$. Titanium reagent ( $2 \% \mathrm{TiCl}_{2}$ in conc. $\mathrm{HCl}$ ) was added to a known volume of extract supernatant to give a $\mathrm{Ti}$ (IV) concentration of $2 \%$. The Ti- $\mathrm{H}_{2} \mathrm{O}_{2}$ complex, together with unreacted $\mathrm{Ti}$, was then precipitated by adding 
$0.2 \mathrm{~cm}^{3} 17 \mathrm{M}$ ammonia solution for each $1 \mathrm{~cm}^{3}$ of extract, then centrifuged at $4000 \mathrm{~g}$ for $15 \mathrm{~min}$, after centrifugation the supernatant was discarded. The precipitate was washed five times with ice acetone by resuspension, drained in $1 \mathrm{M} \mathrm{H}_{2} \mathrm{SO}_{4}\left(3 \mathrm{~cm}^{3}\right)$. The absorbance of the solution was measured at $410 \mathrm{~nm}$ against blanks, which had been similarly prepared but without plant tissue (Simaei et al., 2011).

\subsection{Enzyme extraction and enzyme assays}

For the extraction of antioxidant enzymes, fresh samples were homogenized with $50 \mathrm{mM} \mathrm{Na} \mathrm{N}_{2} \mathrm{H}$ $\mathrm{PO}_{4}-\mathrm{NaH}_{2} \mathrm{PO}_{4}$ buffer ( $\mathrm{pH} 7.8$ ) containing $0.2 \mathrm{mM}$ EDTA and 2\% insoluble polyvinylpyrrolidone in a chilled mortar and pestle. The homogenate was centrifuged at $12,000 \times g$ for $20 \mathrm{~min}$ and the resulted supernatant was used for determination of enzyme activities. The whole extraction procedure was carried out at $4^{\circ} \mathrm{C}$. All spectrophotometric analysis was conducted on a spectrophotometer. Superoxide dismutase (SOD) activity was assayed by measuring its ability to inhibit the photochemical reduction of nitroblue tetrazolium following the method of Tian et al. (2015). Peroxidase (POD) activity was measured by the increase in absorbance at $470 \mathrm{~nm}$ due to guaiacol oxidation (Dong et al., 2016). Catalase (CAT) activity was measured as the decline in absorbance at $240 \mathrm{~nm}$ due to the decrease of extinction of $\mathrm{H}_{2} \mathrm{O}_{2}$ according to the method of Tian et al. (2015).

\subsection{Determination of ion concentration}

For estimation of plant dry matter and concentrations of mineral nutrients in plant, the plant samples were oven-dried for $30 \mathrm{~min}$ at $105^{\circ} \mathrm{C}$, then at $80^{\circ} \mathrm{C}$ till the materials reach their constant weights.
Approximately $0.1 \mathrm{~g}$ dried material of the leaves and roots were completely digested with $5 \mathrm{ml} 98$ $\% \mathrm{H}_{2} \mathrm{SO}_{4}$ at $200{ }^{\circ} \mathrm{C}$, supplemented with a few drops of $\mathrm{H}_{2} \mathrm{O}_{2}(30 \%, \mathrm{v} / \mathrm{v})$. After digestion, each sample was brought up to a $25 \mathrm{ml}$ final volume with distilled-deionized water. $\mathrm{Na}, \mathrm{K}, \mathrm{Ca}, \mathrm{Mg}$, $\mathrm{Zn}$ and Fe contents were measured by atomic absorbance spectrometry (Persee TAS-990, Beijing, China).

\subsection{Statistical analysis}

The analysis of variance (ANOVA) was performed using SAS software (SAS Institute, Cary NC). Differences between treatments were separated by the least significant difference (LSD) test at a 0.05 probability level.

\section{Results}

\subsection{Plant growth and and $R W C$}

Compared to the control (CK), spray of $10 \mathrm{nM}$ and $1 \mathrm{nM}$ EBR under non-stress conditions significantly increased the fresh and dry weight of wheat shoots and roots, but the $100 \mathrm{nM}$ EBR had no significant effect. $120 \mathrm{mM} \mathrm{NaCl}$ stress significantly decreased plant growth $(P \leq 0.05)$, with a reduction of 30.90 and $50.63 \%$ of shoots and roots FW, respectively (Table 1). The RWC of shoots and roots treated with $120 \mathrm{mM} \mathrm{NaCl}$ was obviously lower than CK. Spray of EBR reversed the decline, with The $\mathrm{NaCl}+\mathrm{EBR} 2$ (10 nM EBR) treatment had the best effect of alleviation. Taken together, the alleviating effect of EBR under salt stress was found in a general trend of $10 \mathrm{nM} \mathrm{EBR}$ $>1 \mathrm{nM} \mathrm{EBR}>100 \mathrm{nM}$ EBR. 
Table 1. Effects of exogenous 24-Epibrassinolide on the fresh and dry weight $\left[\mathrm{g}(10 \text { plants })^{-1}\right]$ of wheat shoots and roots under salt stress. Means $\mathrm{SD}, n=3$. Different letters after means within the same column indicate significant differences at $P \leq 0.05$.

\begin{tabular}{|c|c|c|c|c|c|c|}
\hline \multirow{2}{*}{ Treatments } & \multicolumn{3}{|c|}{ Shoots } & \multicolumn{3}{|c|}{ Roots } \\
\hline & Fresh weight & Dry weight & RWC (\%) & Fresh weight & Dry weight & RWC (\%) \\
\hline CK & $4.01 \pm 0.11 \mathrm{~cd}$ & $0.51 \pm 0.02 \mathrm{~cd}$ & $87.27 \pm 0.70 \mathrm{a}$ & $0.87 \pm 0.04 \mathrm{bc}$ & $0.09 \pm 0.01 \mathrm{ab}$ & $89.65 \pm 0.22 \mathrm{ab}$ \\
\hline $\mathrm{NaCl}$ & $2.77 \pm 0.18 \mathrm{f}$ & $0.40 \pm 0.02 \mathrm{~g}$ & $85.40 \pm 0.47 \mathrm{~b}$ & $0.43 \pm 0.03 \mathrm{e}$ & $0.05 \pm 0.00 \mathrm{~d}$ & $87.31 \pm 0.51 \mathrm{c}$ \\
\hline EBR1 & $4.30 \pm 0.27 \mathrm{bc}$ & $0.54 \pm 0.04 \mathrm{c}$ & $87.41 \pm 0.48 \mathrm{a}$ & $0.89 \pm 0.09 \mathrm{bc}$ & $0.09 \pm 0.01 \mathrm{ab}$ & $89.82 \pm 0.69 \mathrm{ab}$ \\
\hline EBR2 & $5.56 \pm 0.44 \mathrm{a}$ & $0.66 \pm 0.02 \mathrm{a}$ & $88.15 \pm 1.03 \mathrm{a}$ & $1.06 \pm 0.09 \mathrm{a}$ & $0.10 \pm 0.01 \mathrm{a}$ & $90.72 \pm 1.31 \mathrm{a}$ \\
\hline EBR3 & $4.55 \pm 0.46 \mathrm{~b}$ & $0.60 \pm 0.01 \mathrm{~b}$ & $86.67 \pm 1.25 \mathrm{ab}$ & $0.95 \pm 0.13 \mathrm{ab}$ & $0.10 \pm 0.01 \mathrm{a}$ & $89.85 \pm 1.71 \mathrm{ab}$ \\
\hline $\mathrm{NaCl}+\mathrm{EBR} 1$ & $2.93 \pm 0.01 \mathrm{f}$ & $0.43 \pm 0.01 \mathrm{fg}$ & $85.47 \pm 0.14 \mathrm{~b}$ & $0.46 \pm 0.04 \mathrm{e}$ & $0.06 \pm 0.00 \mathrm{~d}$ & $87.34 \pm 1.40 \mathrm{c}$ \\
\hline $\mathrm{NaCl}+\mathrm{EBR} 2$ & $3.58 \pm 0.33 \mathrm{de}$ & $0.47 \pm 0.03 \mathrm{de}$ & $86.65 \pm 2.11 \mathrm{ab}$ & $0.77 \pm 0.02 \mathrm{c}$ & $0.08 \pm 0.01 \mathrm{bc}$ & $89.45 \pm 0.43 \mathrm{ab}$ \\
\hline $\mathrm{NaCl}+\mathrm{EBR} 3$ & $3.45 \pm 0.20 \mathrm{e}$ & $0.46 \pm 0.04 \mathrm{ef}$ & $86.62 \pm 0.73 \mathrm{ab}$ & $0.62 \pm 0.04 \mathrm{~d}$ & $0.07 \pm 0.01 \mathrm{c}$ & $88.24 \pm 0.81 \mathrm{bc}$ \\
\hline
\end{tabular}

\subsection{Chlorophyll content}

Table 2 showed the spray of EBR under non-stress conditions increased the total chlorophyll, $\operatorname{chl} a, \operatorname{chl} b$ and carotenoids concentrations in leaves of wheat seedlings compared with CK, especially $10 \mathrm{nM}$ EBR. The total chlorophyll, $\operatorname{chl} a, \operatorname{chl} b$ and carotenoids contents showed a significant decrease on $\mathrm{NaCl}$-alone treatment $(20.12$, 20.63, 20.51 and $25.93 \%$ respect to CK). However, when treated with $\mathrm{EBR}(100,10$ or $1 \mathrm{nM})$ in the presence of salt stress, this inhibition was alleviated. The $\mathrm{NaCl}$ + EBR1, $\mathrm{NaCl}+\mathrm{EBR} 2$ and $\mathrm{NaCl}+\mathrm{EBR} 3$ treatments increased total chlorophyll by $10.69,21.37$ and $17.56 \%$ than $\mathrm{NaCl}$ treatment. And the best of alleviating effect on increasing total chlorophyll content was $\mathrm{NaCl}+\mathrm{EBR} 2$ treatment. Similar findings were found for the $\operatorname{chl} a, \operatorname{chl} b$ and carotenoids contents.

Table 2. Effects of exogenous 24-Epibrassinolide on the chlorophyll contents [ $\mathrm{mg} \mathrm{g}^{-1}$ (f.m.)] in leaves of wheat seedlings under salt stress. Means $\mathrm{SD}, n=3$. Different letters after means within the same column indicate significant differences at $P \leq 0.05$.

\begin{tabular}{ccccc}
\hline Treatments & Total Chl contents & Chl $a$ & Chl $b$ & Carotenoids $x . c$ \\
\hline $\mathrm{CK}$ & $1.64 \pm 0.02 \mathrm{c}$ & $1.26 \pm 0.01 \mathrm{c}$ & $0.39 \pm 0.01 \mathrm{bc}$ & $0.27 \pm 0.01 \mathrm{bc}$ \\
$\mathrm{NaCl}$ & $1.31 \pm 0.05 \mathrm{f}$ & $1.00 \pm 0.03 \mathrm{f}$ & $0.31 \pm 0.01 \mathrm{e}$ & $0.20 \pm 0.03 \mathrm{~d}$ \\
$\mathrm{EBR} 1$ & $1.65 \pm 0.03 \mathrm{c}$ & $1.27 \pm 0.03 \mathrm{c}$ & $0.38 \pm 0.01 \mathrm{bc}$ & $0.28 \pm 0.01 \mathrm{~b}$ \\
$\mathrm{EBR} 2$ & $1.89 \pm 0.08 \mathrm{a}$ & $1.45 \pm 0.07 \mathrm{a}$ & $0.43 \pm 0.01 \mathrm{a}$ & $0.31 \pm 0.02 \mathrm{a}$ \\
$\mathrm{EBR} 3$ & $1.75 \pm 0.05 \mathrm{~b}$ & $1.34 \pm 0.01 \mathrm{~b}$ & $0.41 \pm 0.03 \mathrm{ab}$ & $0.28 \pm 0.02 \mathrm{~b}$ \\
$\mathrm{NaCl}+\mathrm{EBR} 1$ & $1.45 \pm 0.07 \mathrm{e}$ & $1.12 \pm 0.05 \mathrm{e}$ & $0.33 \pm 0.02 \mathrm{de}$ & $0.25 \pm 0.01 \mathrm{c}$ \\
$\mathrm{NaCl}+\mathrm{EBR} 2$ & $1.59 \pm 0.01 \mathrm{~cd}$ & $1.23 \pm 0.01 \mathrm{~cd}$ & $0.37 \pm 0.00 \mathrm{c}$ & $0.27 \pm 0.01 \mathrm{bc}$ \\
$\mathrm{NaCl}+\mathrm{EBR} 3$ & $1.54 \pm 0.02 \mathrm{~d}$ & $1.18 \pm 0.02 \mathrm{de}$ & $0.36 \pm 0.02 \mathrm{~cd}$ & $0.26 \pm 0.01 \mathrm{bc}$
\end{tabular}




\subsection{Root activity and $\mathrm{H}^{+}$-ATPase activity}

Spray of EBR under non-stress conditions increased root activity and $\mathrm{H}^{+}$-ATPase activity of wheat seedlings compared with CK, especially $10 \mathrm{nM}$ EBR (Figure 1). Treatment with $\mathrm{NaCl}$ decreased root activity by $52.10 \%$
(Figure 1A) and $\mathrm{H}^{+}$-ATPase activity by $42.99 \%$ (Figure 1B) than CK. However, this inhibition was alleviated with spray of $\mathrm{EBR}$, and $\mathrm{NaCl}+\mathrm{EBR} 2$ treatment had the best alleviating effect. The foliar application of $10 \mathrm{nM}$ EBR increased root activity by $89.88 \%$ and $\mathrm{H}^{+}$-ATPase activity by $65.49 \%$ than $\mathrm{NaCl}$-alone treatment.

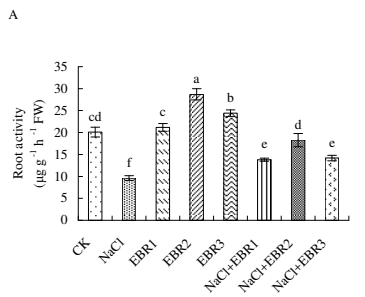

B
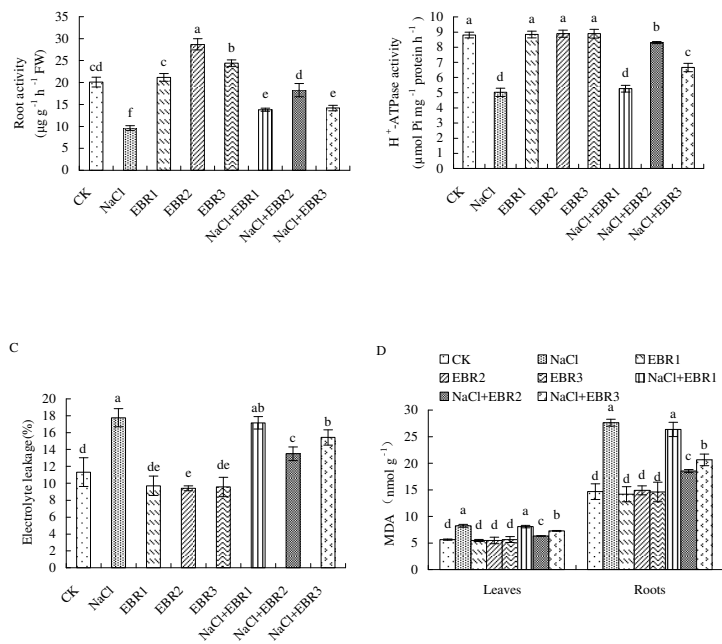

Figure 1. Effects of exogenous 24-Epibrassinolide on root activity (A), $\mathrm{H}^{+}$-ATPase activity (B), Electrolyte leakage $(C)$ and lipid peroxidation (D) of wheat seedlings under salt stress. Values represent mean $\pm \mathrm{SD}(\mathrm{n}=3)$. Different small letters within the same row indicate significant difference at $P \leq 0.05$.

\subsection{Electrolyte leakage and lipid peroxidation}

Figure 1 showed that electrolyte leakage and MDA content in leaves or roots of wheat seedlings on EBR1, EBR2 and EBR3 treatments had no significant changes compared with CK. The salinity caused electrolyte leakage and MDA accumulation in plants. Electrolyte leakage in leaves of wheat plants seedlings increased dramatically after 15 days of $\mathrm{NaCl}$ treatment relative to $\mathrm{CK}$, while the increase was lower in plants treated with 1 and 10nM EBR (Figure 1C). The electrolyte leakages on $\mathrm{NaCl}+\mathrm{EBR} 2$ and $\mathrm{NaCl}+\mathrm{EBR} 3$ treatments were lower by $24.07 \%$ and by $13.15 \%$ than in NaCl-treated plants. However, the $100 \mathrm{nM}$ EBR had no significant effect. Malondialdehyde content was measured as an index of lipid peroxidation. $\mathrm{NaCl}$-alone treatment induced a significant increase in MDA content of wheat seedlings, which was increased by $45.97 \%$ in leaves and by $88.37 \%$ in roots compared with CK (Figure 1D). However, the application of exogenous EBR reduced MDA accumulation; and the $10 \mathrm{nM}$ EBR markedly reduced $\mathrm{NaCl}$-induced MDA accumulation; MDA content decreased by $23.24 \%$ in leaves and by $32.92 \%$ in roots compared with $\mathrm{NaCl}$ treatment. 


\subsection{Osmotic regulator accumulation}

The level of proline exhibited an increase in response to salinity stress, both in the leaves and roots of wheat plants, compared to $\mathrm{CK}$ (Figure 2A). The $\mathrm{NaCl}$ treatment increased proline content by $58.12 \%$ in leaves and by $90.75 \%$ in roots as compared to those of control. The quantity of proline was higher in leaves than the roots. The spray of EBR on unstressed plant brought about a significant decrease in the level of proline in leaves, but could not bring about a significant change in roots. However, the application of EBR under salinity stress elevated the quantity of proline, both in leaves and roots. The maximum quantity of proline was found in the plants which were subjected to both $\mathrm{NaCl}$ stress and subsequently sprayed with $10 \mathrm{nM} \mathrm{EBR}$, and the $100 \mathrm{nM}$ EBR could not bring about a significant change in the level of proline. Compared to $\mathrm{NaCl}$ treatment, the proline content in leaves and roots increased by $62.17 \%$ and by $16.14 \%$ under the $\mathrm{NaCl}+\mathrm{EBR} 2$ treatment.

The spray of EBR on unstressed plant could not bring about a significant change in the level of protein (Figure 2B). Soluble protein concentration decreased in leaves but increased in roots after $\mathrm{NaCl}$ treatment. However, higher protein content was detected in plants treated with EBR under salt stress both in leaves and roots as compared to only salt-treated plants. The increase was significant especially in the plants treated with $10 \mathrm{nM}$ EBR.
A
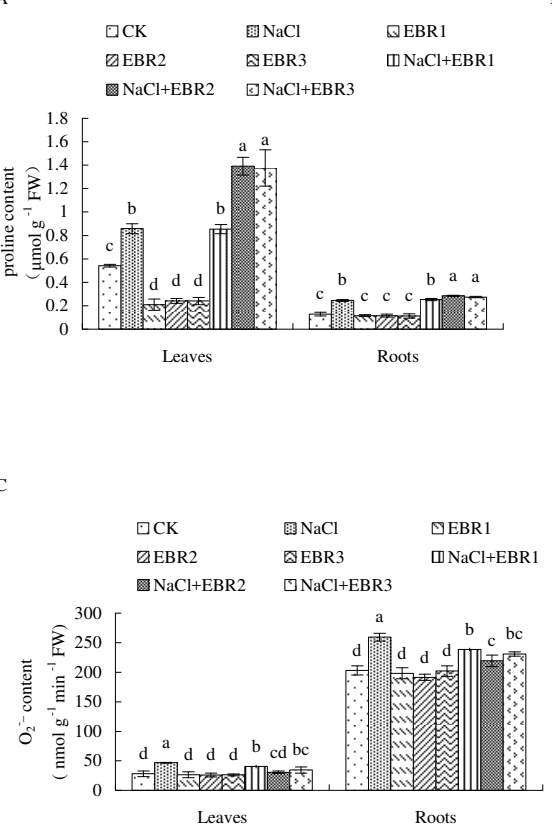
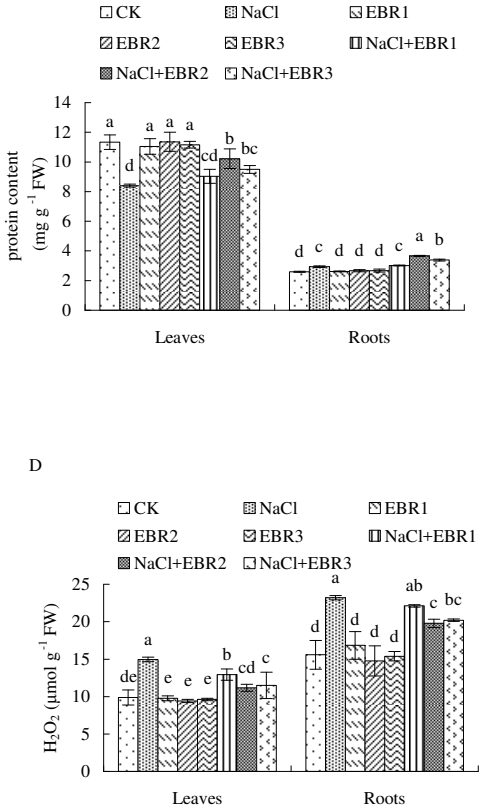

Figure 2. Effects of exogenous 24-Epibrassinolide on proline (A), protein content (B), $\mathrm{O}_{2}$ - generation rate (C) and $\mathrm{H}_{2} \mathrm{O}_{2}$ content (D) of wheat seedlings under salt stress. Values represent mean $\pm \mathrm{SD}(\mathrm{n}=3)$. Different small letters within the same row indicate significant difference at $P \leq 0.05$. 


\section{6. $\mathrm{O}_{2}$ generation rate and $\mathrm{H}_{2} \mathrm{O}_{2}$ content}

As shown in Figure 2C and Figure 2D, the spray of EBR on unstressed wheat seedlings could not bring about a significant change in the levels of $\mathrm{O}_{2}$ - generation rate and $\mathrm{H}_{2} \mathrm{O}_{2}$ content. $120 \mathrm{mM} \mathrm{NaCl}$ treatment induced a dramatic increase in $\mathrm{O}_{2}-$ and $\mathrm{H}_{2} \mathrm{O}_{2}$ production in leaves and roots of wheat seedlings compared with CK. Spray of EBR significantly diminished $\mathrm{NaCl}$ induced ROS accumulation in leaves and roots, especially $10 \mathrm{nM}$ EBR. The $\mathrm{O}_{2}{ }^{-}$generation rate and $\mathrm{H}_{2} \mathrm{O}_{2}$ content under $\mathrm{NaCl}+\mathrm{EBR} 2$ treatment were decreased by $34.43,25.30 \%$ in leaves and by 15.39 , $14.76 \%$ in roots compared with $\mathrm{NaCl}$ treatment.

\subsection{Antioxidant enzymes}

Results in Figure 3 demonstrated that the spray of EBR under non-stress conditions increased the ac- tivities of SOD, POD, and CAT in leaves and roots of wheat seedlings compared with CK, especially $10 \mathrm{nM}$ EBR. Salt stress significantly decreased the activity of SOD in the wheat leaves and roots (Figure 3A), but application of EBR alleviated the decline of the SOD activity under salt stress. The $10 \mathrm{nM}$ EBR had the best alleviating effect.

Compared to CK, the POD activity under salt stress decreased significantly in leaves; but it increased markedly in roots (Figure 3B). When treated with EBR in the presence of salt stress, the POD activity exhibited an increase, both in the leaves and roots, especially $10 \mathrm{nM}$ EBR.

Salt stress increased the activity of CAT in the wheat leaves and roots (Figure 3C), and application of EBR under salt stress elevated the increase of CAT activity, especially $10 \mathrm{nM}$ EBR.

B

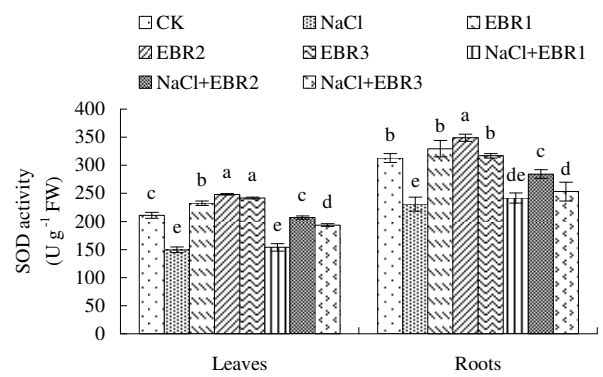

C

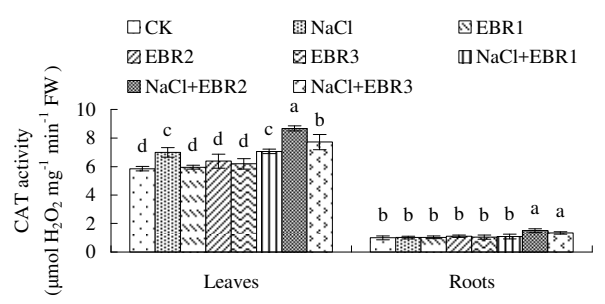

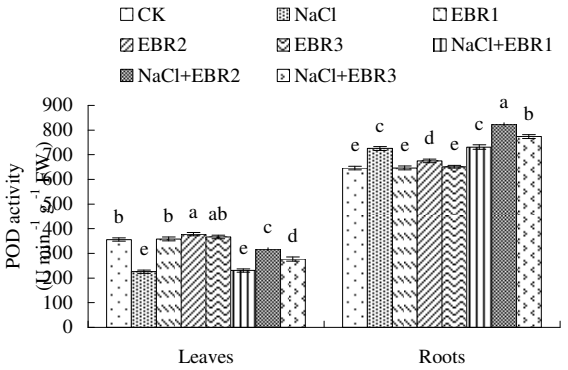

Figure 3. Effects of exogenous 24-Epibrassinolide on SOD (A), POD (B) and CAT (C) content in leaves and roots of wheat seedlings under salt stress. Values represent mean $\pm \mathrm{SD}(\mathrm{n}=3)$. Different small letters within the same row indicate significant difference at $P \leq 0.05$. 


\subsection{Mineral nutrient concentration}

As showed in Table 3, the spray of low concentration EBR (1 and 10nM EBR) on unstressed plant could increase the contents of mineral nutrients ( $\mathrm{K}, \mathrm{Ca}, \mathrm{Mg}, \mathrm{Fe}$ and $\mathrm{Zn}$ ). A high concentration of $\mathrm{Na}$ was observed in the treatment of $\mathrm{NaCl}$ alone, and concentrations of all the mineral nutrients ( $\mathrm{K}, \mathrm{Ca}, \mathrm{Mg}$, Fe and $\mathrm{Zn}$ ) under $\mathrm{NaCl}$ treatment were lower than those of CK. However, the application of EBR under salt stress alleviated the decline, especially $10 \mathrm{nM}$
EBR. When treated with $10 \mathrm{nM} E B R$ in the presence of salt stress, the concentrations of $\mathrm{K}, \mathrm{Ca}, \mathrm{Mg}, \mathrm{Fe}$ and $\mathrm{Zn}$ were increased by $7.30,54.61,7.56,30.31$, and $19.19 \%$ in leaves and by $27.78,64.88,46.94,82.00,33.26 \%$ in roots, respectively as compared to $\mathrm{NaCl}$-alone treatment. However, the $100 \mathrm{nM}$ EBR had no significant effect. The $\mathrm{K} / \mathrm{Na}$ and $\mathrm{Ca} / \mathrm{Na}$ ratios significantly decreased in wheat seedlings under saline conditions (Table 4). However, the spray of EBR increased $\mathrm{K} / \mathrm{Na}$ and $\mathrm{Ca} / \mathrm{Na}$ ratios in leaves and roots, especially $10 \mathrm{nM} \mathrm{EBR}$.

Table 3. Effects of exogenous 24-Epibrassinolide on the concentrations of $\mathrm{K}, \mathrm{Na}, \mathrm{Ca}, \mathrm{Mg}, \mathrm{Fe}$ [g kg-1 (d.m.)], Zn $\left[\mathrm{mg} \mathrm{kg}^{-1}\right.$ (d.m.)] in the leaves and roots of wheat seedlings under salt stress. Means SD, $n=3$. Different letters after means within the same column indicate significant differences at $P \leq 0.05$.

\begin{tabular}{|c|c|c|c|c|c|c|c|c|c|}
\hline \multirow{3}{*}{ Element } & Tissue & \multirow{3}{*}{ CK } & \multirow{3}{*}{$\mathrm{NaCl}$} & \multirow{3}{*}{ EBR1 } & \multirow{3}{*}{ EBR2 } & \multirow{3}{*}{ EBR3 } & \multirow{3}{*}{$\mathrm{NaCl}+\mathrm{EBR} 1$} & \multirow{3}{*}{$\mathrm{NaCl}+\mathrm{EBR} 2$} & \multirow{3}{*}{$\mathrm{NaCl}+\mathrm{EBR} 3$} \\
\hline & & & & & & & & & \\
\hline & Treaments & & & & & & & & \\
\hline \multirow{3}{*}{ K } & Leaves & $20.45 \pm 0.89 \mathrm{a}$ & $17.94 \pm 0.35 \mathrm{~d}$ & $20.02 \pm 0.87 \mathrm{ab}$ & $19.99 \pm 0.38 \mathrm{ab}$ & $20.03 \pm 0.62 \mathrm{ab}$ & $18.52 \pm 0.43 \mathrm{~cd}$ & $19.25 \pm 0.38 \mathrm{bc}$ & $19.23 \pm 0.64 \mathrm{bc}$ \\
\hline & & & & & & & & & \\
\hline & Roots & $21.75 \pm 0.61 \mathrm{c}$ & $11.77 \pm 0.48 \mathrm{e}$ & $25.94 \pm 0.43 \mathrm{a}$ & $23.37 \pm 1.09 \mathrm{~b}$ & $25.97 \pm 0.86 \mathrm{a}$ & $12.73 \pm 0.51 \mathrm{e}$ & $15.04 \pm 1.49 \mathrm{~d}$ & $14.33 \pm 0.73 \mathrm{~d}$ \\
\hline \multirow{3}{*}{$\mathrm{Na}$} & Leaves & $4.32 \pm 0.61 \mathrm{c}$ & $9.06 \pm 0.22 \mathrm{a}$ & $3.72 \pm 0.25 \mathrm{~d}$ & $3.49 \pm 0.12 \mathrm{~d}$ & $4.02 \pm 0.25 \mathrm{~cd}$ & $8.50 \pm 0.18 \mathrm{~b}$ & $8.11 \pm 0.37 \mathrm{~b}$ & $8.00 \pm 0.18 \mathrm{~b}$ \\
\hline & & & & & & & & & \\
\hline & Roots & $9.24 \pm 1.06 \mathrm{c}$ & $14.22 \pm 0.63 \mathrm{a}$ & $8.64 \pm 0.55 \mathrm{~cd}$ & $7.54 \pm 0.11 \mathrm{~d}$ & $7.38 \pm 1.63 \mathrm{~d}$ & $14.05 \pm 0.26 \mathrm{a}$ & $12.64 \pm 0.50 \mathrm{~b}$ & $13.25 \pm 0.52 \mathrm{ab}$ \\
\hline \multirow{3}{*}{$\mathrm{Ca}$} & Leaves & $5.25 \pm 0.49 \mathrm{~b}$ & $3.42 \pm 0.69 \mathrm{c}$ & $5.36 \pm 0.65 \mathrm{~b}$ & $7.06 \pm 1.50 \mathrm{a}$ & $8.15 \pm 0.41 \mathrm{a}$ & $4.74 \pm 0.69 \mathrm{bc}$ & $5.28 \pm 1.38 \mathrm{~b}$ & $5.25 \pm 1.28 \mathrm{~b}$ \\
\hline & & & & & & & & & \\
\hline & Roots & $3.16 \pm 0.25 \mathrm{~b}$ & $1.56 \pm 0.08 \mathrm{~d}$ & $2.74 \pm 0.09 \mathrm{bc}$ & $4.14 \pm 0.87 \mathrm{a}$ & $2.75 \pm 0.34 \mathrm{bc}$ & $2.44 \pm 0.18 \mathrm{c}$ & $2.57 \pm 0.16 \mathrm{bc}$ & $2.25 \pm 0.09 \mathrm{c}$ \\
\hline \multirow{3}{*}{$\mathrm{Mg}$} & Leaves & $0.83 \pm 0.09 \mathrm{~b}$ & $0.74 \pm 0.01 \mathrm{c}$ & $0.85 \pm 0.05 \mathrm{~b}$ & $0.94 \pm 0.03 \mathrm{a}$ & $0.94 \pm 0.05 \mathrm{a}$ & $0.80 \pm 0.02 \mathrm{bc}$ & $0.80 \pm 0.03 \mathrm{bc}$ & $0.79 \pm 0.02 \mathrm{bc}$ \\
\hline & & & & & & & & & \\
\hline & Roots & $0.83 \pm 0.05 \mathrm{bc}$ & $0.52 \pm 0.04 \mathrm{e}$ & $0.81 \pm 0.02 \mathrm{bc}$ & $1.02 \pm 0.08 \mathrm{a}$ & $0.86 \pm 0.02 \mathrm{~b}$ & $0.63 \pm 0.01 \mathrm{~d}$ & $0.77 \pm 0.04 \mathrm{c}$ & $0.64 \pm 0.07 \mathrm{~d}$ \\
\hline \multirow{3}{*}{$\mathrm{Fe}$} & Leaves & $1.24 \pm 0.10 \mathrm{a}$ & $0.89 \pm 0.07 \mathrm{c}$ & $1.25 \pm 0.26 \mathrm{a}$ & $1.26 \pm 0.17 \mathrm{a}$ & $1.26 \pm 0.07 \mathrm{a}$ & $0.94 \pm 0.05 \mathrm{bc}$ & $1.16 \pm 0.13 \mathrm{ab}$ & $1.14 \pm 0.18 \mathrm{ab}$ \\
\hline & & & & & & & & & \\
\hline & Roots & $4.60 \pm 0.24 \mathrm{a}$ & $1.74 \pm 0.20 \mathrm{~d}$ & $4.65 \pm 0.17 \mathrm{a}$ & $4.69 \pm 0.17 \mathrm{a}$ & $4.66 \pm 0.15 \mathrm{a}$ & $2.19 \pm 0.34 \mathrm{~cd}$ & $3.16 \pm 0.51 b$ & $2.42 \pm 0.29 \mathrm{c}$ \\
\hline \multirow{3}{*}{$\mathrm{Zn}$} & Leaves & $67.06 \pm 2.53 \mathrm{a}$ & $46.04 \pm 6.52 \mathrm{c}$ & $65.99 \pm 3.19 \mathrm{a}$ & $69.14 \pm 1.82 \mathrm{a}$ & $66.51 \pm 4.48 \mathrm{a}$ & $52.94 \pm 5.27 \mathrm{bc}$ & $54.87 \pm 6.32 \mathrm{~b}$ & $53.26 \pm 5.52 \mathrm{bc}$ \\
\hline & & & & & & & & & \\
\hline & Roots & $100.10 \pm 8.72 \mathrm{a}$ & $73.54 \pm 6.30 \mathrm{c}$ & $95.94 \pm 8.10 \mathrm{a}$ & $101.82 \pm 8.63 \mathrm{a}$ & $99.43 \pm 5.68 \mathrm{a}$ & $83.67 \pm 8.95 \mathrm{bc}$ & $98.00 \pm 3.09 \mathrm{a}$ & $94.26 \pm 2.97 \mathrm{ab}$ \\
\hline
\end{tabular}

Table 4. Effects of exogenous 24-Epibrassinolide on $\mathrm{K} / \mathrm{Na}$ and $\mathrm{Ca} / \mathrm{Na}$ ratios in the leaves and roots of wheat seedlings under salt stress. Means $\mathrm{SD}, n=3$. Different letters after means within the same column indicate significant differences at $P \leq 0.05$.

\begin{tabular}{cccccccccc}
\hline Parameters & Tissue/Treaments & $\mathrm{CK}$ & $\mathrm{NaCl}$ & $\mathrm{EBR} 1$ & $\mathrm{EBR} 2$ & $\mathrm{EBR} 3$ & $\mathrm{NaCl}+\mathrm{EBR} 1$ & $\mathrm{NaCl}+\mathrm{EBR} 2$ & $\mathrm{NaCl}+\mathrm{EBR} 3$ \\
\hline \multirow{2}{*}{$\mathrm{K} / \mathrm{Na}$} & Leaves & $4.78 \pm 0.56 \mathrm{c}$ & $1.98 \pm 0.01 \mathrm{~d}$ & $5.39 \pm 0.32 \mathrm{ab}$ & $5.72 \pm 0.08 \mathrm{a}$ & $5.00 \pm 0.38 \mathrm{bc}$ & $2.18 \pm 0.09 \mathrm{~d}$ & $2.38 \pm 0.15 \mathrm{~d}$ & $2.40 \pm 0.06 \mathrm{~d}$ \\
& Roots & $2.37 \pm 0.23 \mathrm{c}$ & $0.83 \pm 0.06 \mathrm{~d}$ & $3.01 \pm 0.14 \mathrm{~b}$ & $3.10 \pm 0.12 \mathrm{~b}$ & $3.61 \pm 0.61 \mathrm{a}$ & $0.91 \pm 0.05 \mathrm{~d}$ & $1.19 \pm 0.12 \mathrm{~d}$ & $1.08 \pm 0.09 \mathrm{~d}$ \\
& Leaves & $1.24 \pm 0.31 \mathrm{~b}$ & $0.38 \pm 0.07 \mathrm{c}$ & $1.44 \pm 0.09 \mathrm{~b}$ & $2.03 \pm 0.49 \mathrm{a}$ & $2.03 \pm 0.04 \mathrm{a}$ & $0.56 \pm 0.09 \mathrm{c}$ & $0.65 \pm 0.14 \mathrm{c}$ & $0.66 \pm 0.17 \mathrm{c}$ \\
$\mathrm{Ca} / \mathrm{Na}$ & Roots & $0.34 \pm 0.04 \mathrm{~b}$ & $0.11 \pm 0.01 \mathrm{c}$ & $0.32 \pm 0.03 \mathrm{~b}$ & $0.55 \pm 0.11 \mathrm{a}$ & $0.38 \pm 0.10 \mathrm{~b}$ & $0.17 \pm 0.02 \mathrm{c}$ & $0.20 \pm 0.02 \mathrm{c}$ & $0.17 \pm 0.01 \mathrm{c}$ \\
\hline
\end{tabular}




\section{Discussion}

As demonstrated, exogenous application of very low BRs concentrations influences multiple plant growth and development processes, while micromolar concentrations cause inhibitory effects (Choudhary et al., 2012). In the present study, spray of EBR under non-stress conditions increased the fresh and dry weight of wheat shoots and roots compared with $\mathrm{CK}$, especially $10 \mathrm{nM}$ and $1 \mathrm{nM}$ EBR (Table 1). This study indicated that the low concentrations of EBR could promote wheat plant growth. Wheat seedlings under $\mathrm{NaCl}$ stress exhibited a significant decline in all the growth parameters compared to CK plants (Table 1). These results were in agreement with that of $\mathrm{Li}$ et al. (2013) who showed marked reduction in growth parameters of wheat subjected to $\mathrm{NaCl}$ stress. It has been proposed that this growth inhibition caused by salinity could partly be due to the shortage of energy because processes involved in salt transport and salt damage repair on membrane or proteins are energy consuming (Tian et al., 2015). Tian et al. (2015) also indicated that reduction in the plant growth has been attributed to reduced water absorption due to osmotic effect, nutritional deficiency on account of the ionic imbalance and decrease in many metabolic activities. However, this reduction in growth was alleviated with spray of EBR (Table 1).

Foliar application of low concentrations EBR resulted in significant increases in growth parameters of plants under $120 \mathrm{mM} \mathrm{NaCl}$ treatment compared to $\mathrm{CK}$ plants. In the present study, the most effective dose of EBR under saline conditions was found to be 10 nM EBR. Similar results were observed in Medicago truncatula (López-Gómez et al., 2016) and strawberry (Karlidag et al., 2011), which was found that foliar application of 24-EBL was effective in improving growth, in terms of increasing plant fresh and dry biomass under both non-saline and saline conditions.
RWC is considered as an alternative measure of plant water status, reflecting the metabolic activity in plant tissues (Tian et al., 2015). Table 1 showed that salt stress significantly declined RWC in leaves and roots compared to CK treatment. Spray of EBR under salt stress increased the RWC compared with only $\mathrm{NaCl}$ treatment, especially $10 \mathrm{nM}$ EBR. Increased RWC by BRs application had been reported for Brassica juncea (Hayat et al., 2010) under cadmium stress and $\mathrm{Vi}$ gna radiata (Ali et al., 2008) under aluminium stress. It is known that at non-stress conditions various BRs are proposed to regulate photosynthesis. Salt stress significantly decreased the total chlorophyll, chl $a$, chl $b$ and carotenoids concentrations in leaves of wheat seedlings compared to CK (Table 2). Similarly, Sharma et al. (2013) indicated that $\mathrm{NaCl}$ stress caused a significant reduction in the chlorophyll concentration. This decrease in chlorophyll concentration may be attributed to the increase in the activity of chlorophyll degrading enzyme chlorophylase, under saline conditions (Tian et al., 2015). However, application of EBR under salt stress elevated the chlorophyll content (Table 2). This positive effect can be reasoned from the possibility of BRs-induced impact on transcription and/or translation in the synthesis of pigments (Bajguz, 2000). These results were in agreement with some earlier reports in which it has been observed that 24-EBL could ameliorate the decrease in chlorophyll content caused by aluminium stress (Dong et al., 2008) and weak light stress (Wang et al., 2010). In the present study, the spray of EBR on unstressed plant could promote wheat plant growth by increasing root activity and $\mathrm{H}^{+}$-ATPase activity (Figure 1A, B), which might be responsible for root activity can directly affect the shoot growth, nutrition status, and $\mathrm{H}^{+}$-ATPase plays a major role in the activation of ion and nutrient transport (Frédéric et al., 2007). $\mathrm{NaCl}$ treatment significantly lowered root activity and $\mathrm{H}^{+}$ATPase activity, whereas spray of EBR mitigated the 
salt effect, and $\mathrm{NaCl}+\mathrm{EBR} 2$ treatment had the best effect (Figure 1A, B). Khripach et al. (2000) have demonstrated that EBR could regulate cell elongation and divisional activities by activating cell wall loosening enzymes. Song et al. (2016) also indicated that EBR could induce $\mathrm{H}^{+}$-ATPase activity, which may be attributed to EBR increasing absorption of $\mathrm{Ca}, \mathrm{Mg}$ under $\mathrm{NaCl}$ stress.

Electrolyte leakage of wheat plants was higher in 120 $\mathrm{mM} \mathrm{NaCl}$ compared to the nonsaline conditions (Figure 1C). Dong et al. (2015) reported that salt stress led to a significant increase in the level of electrolyte leakage in many crops. In the present study, EBR treated plants under salt stress had less electrolyte leakage compared to only $\mathrm{NaCl}$ treatment. Moreover, BRs are reported to modify the membrane structure/ stability under stress conditions. In this present study, $\mathrm{NaCl}$ treatment significantly increased the level of malondialdehyde in wheat seedlings (Figure 1D). Egbichi et al. (2013) reported that salt stress induced oxidative damage to membrane lipids, as revealed by the amount of malondialdehyde produced in salttreated soybean root nodules. However, spray of EBR under salt stress could decrease production of malondialdehyde in leaves and roots of wheat seedlings (Figure 1D), and the $10 \mathrm{nM}$ EBR had the best effects. However, the data obtained from this study suggests that application of EBR can protect wheat plants from the effect of salt induced-membrane damage. Ali et al. (2008) also demonstrated that application of 24-Epibrassinolide could decrease membrane lipid peroxidation and protect against the stress generated by salinity and nickel in Brassica juncea. But there was no marked difference in the lipid peroxidation level between the $\mathrm{NaCl}$-alone treatment and $\mathrm{NaCl}+\mathrm{EBR} 1$ treatment. This result indicated that the appropriate concentrations of EBR could alleviate salt stress induced oxidative damage to membrane lipids.
Salinity causes a lot of physiological and morphological changes including the accumulation of low molecular weight compounds called compatible solutes such as proline (Chen et al., 2007). In this present study, salt stress significantly increased proline content in leaves and roots of wheat seedlings compared with CK (Figure 2A). Proline, under stress conditions acts as osmoprotectant, membrane stabilizer and ROS scavenger (Dong et al., 2015). Osmotic adjustment is the main part of the physiological machinery by which plants respond to salt stress. Accumulation of protein in the cytosol and other organelles helps in the osmotic adjustment of plants. Recent studies demonstrated that EBR could alleviate the detrimental effects of different stresses on the plant growth by improving photosynthesis in leaves, mainly due to upregulation of the levels of protein and proline content (Sharma et al., 2013; Zhang et al., 2013). These results were in agreement with the present study in which it has been observed that Spray of EBR increased the proline (Figure 2A) and protein content (Figure 2B), thus resulted in an increase in the ability of tolerance to $\mathrm{NaCl}$.

To maintain metabolic functions under stress conditions, the balance between generation and degradation of ROS is required, otherwise oxidative injuries may occur. Overaccumulation of ROS in plant cells is the main effect of $\mathrm{NaCl}$ toxicity (Rady 2011). The accumulation of $\mathrm{O}_{2}-$ and $\mathrm{H}_{2} \mathrm{O}_{2}$ during salinity stress can arise as a result of the imbalance in the rate of production and removal of ROS (Egbichi et al., 2013). In the present study, samples treated with $120 \mathrm{mM} \mathrm{NaCl}$ recorded the highest level of $\mathrm{O}_{2}$-generation rate and $\mathrm{H}_{2} \mathrm{O}_{2}$ content (Figure 2C, D). The result was in agreement with some earlier reports in which it had been observed that salt stress could increase $\mathrm{H}_{2} \mathrm{O}_{2}$ content in rice and barley (Li et al., 2008). Spray of EBR decreased the $\mathrm{O}_{2}$-generation rate and $\mathrm{H}_{2} \mathrm{O}_{2}$ content (Figure $2 \mathrm{C}, \mathrm{D}$ ), and reversed the salinity-induced stress. Ahammed et al. (2013) also indicated that EBR sig- 
nificantly decreased harmful ROS accumulation and lipid peroxidation through the induction of antioxidant enzymes activity.

Plant detoxification pathways consisted of several metabolic processes which include the activation of antioxidant enzymes (Ahammed et al., 2013). SOD is a first line defence enzyme involved in the dismutation of $\mathrm{O}_{2}-$ Again, $\mathrm{H}_{2} \mathrm{O}_{2}$ is converted into water and oxygen by the action of POD, CAT and APX (Song et al., 2016). In the present study, salt stress significantly inhibited SOD and POD activities in leaves and SOD activity in roots of wheat seedlings (Figure 3A, B and C). A decrease in antioxidant enzyme activity suggests that generation of $\mathrm{O}_{2}{ }^{--}$and $\mathrm{H}_{2} \mathrm{O}_{2}$ exceeds the elimination ability of enzymes (Song et al., 2016). Inhibition in antioxidant enzyme activity is consistent with the increased $\mathrm{O}_{2}{ }^{-}$and $\mathrm{H}_{2} \mathrm{O}_{2}$ production and subsequent lipid peroxidation in the current study. However, spray of EBR under $\mathrm{NaCl}$ stress could increase the antioxidant enzyme activity not only in leaves but also in roots (Figure 3A, B and C), thus elevate stress tolerance. EBR could increase the antioxidant enzyme activity, thus elevate stress tolerance. Some early studies also demonstrated that EBR could increase the antioxidant enzyme activity, thus elevate stress tolerance (Mazorra Morales et al., 2014).

Mineral contents of the leaves and roots of the wheat plants except $\mathrm{Na}$ drastically decreased under salt stress (Table 3). It has been shown that high concentrations of $\mathrm{NaCl}$ may disorder nutrient-ion activities, causing plants to be susceptible to osmotic and specific-ion injury as well as to nutritional disorders that result in reduced yield and quality. Mineral nutrients such as $\mathrm{K}$ and $\mathrm{Ca}$ are essentially required for the activities of enzymes, protein synthesis and integrity of cell wall and plasma membrane (Song et al., 2016). $\mathrm{NaCl}$ not only reduces $\mathrm{Ca}$ and $\mathrm{K}$ availability, but reduces $\mathrm{Ca}$ and $\mathrm{K}$ transport and mobility to growing regions of plants. The results were in agreement with the view that plants growing under saline conditions suffer ionic imbalance, nutrient deficiency and specific ion toxicity (Dong et al., 2015). Foliar application of EBR altered the accumulation of mineral contents in the leaves and roots (Table 3). Karlidag et al. (2011) also demonstrated that 24-EBL application significantly increased $\mathrm{K}, \mathrm{Ca}, \mathrm{Mg}, \mathrm{Fe}$ and $\mathrm{Zn}$ content in strawberry plants under salt stress. Foliar application of EBR under salt stress increased $\mathrm{K} / \mathrm{Na}$ and $\mathrm{Ca} / \mathrm{Na}$ ratios compared to only $\mathrm{NaCl}$ treatment (Table 4). Similarly, Shahbaz and Ashraf indicated that foliar spray with $0.0125 \mathrm{mg} \mathrm{L}^{-1}$ EBL increased $\mathrm{K} / \mathrm{Na}$ ratio in salinized plants of MH-97 wheat plants (Song et al., 2016). EBR-induced increase in growth was accompanied with corresponding increase in $\mathrm{K} / \mathrm{Na}$ and $\mathrm{Ca} / \mathrm{Na}$ ratios in the salt stressed plants. Growth promotive effect of BRs might have also been due to its role in ion homeostasis, which is necessary for various biochemical or physiological processes controlling growth (Karlidag et al., 2011).

\section{Conclusions}

Salt stress induced lower plant growth, relative water conter (RWC) and mineral contents of wheat seedlings. However, with spray of exogenous 24-Epibrassinolide (EBR) in wheat plants, the deleterious effects of salinity stress were alleviated. The potential mechanisms include: (1) EBR could increase content of chlorophyll contents, soluble proteins, and free proline; (2) EBR could regulate activities of key antioxidant enzymes to eliminate ROS; (3) EBR could help the wheat plants to improve cell membrane stability and nutrient uptake under salinity stress. Therefore, EBR could improve wheat plant growth under salt stress, and the optimal concentration appears to be $10 \mathrm{nM}$ concentration. The foliar EBR applications could offer a simple application in wheat production in saline soil but further studies are required in order 
to determine the efficiency of these materials under natural field condition.

\section{Acknowledgements}

This work was financially supported by the Project of National Science and Technology Project in Rural Area in 12th Five-Year (2013BAD05B06), the Chinese National Basic Research Program (2015CB150404), the National Key Research and Development Program of China(2017YFD0201705), the Key Research and Development Program of Shandong province (2016CYJS05A02), the Indigenous Innovation project of Shandong Province (2014ZZCX07402),a Project of Shandong Agricultural University saline and alkaline land (75030) and Funds of Shandong "Double Tops" Program.

\section{References}

Ahammed, G.J., Ruan, Y.P., Zhou, J., Xia, X.J., Shi, K., Zhou, Y.H., Yu, J.Q. 2013. Brassinosteroid alleviates polychlorinated biphenyls-induced oxidative stress by enhancing antioxidant enzymes activity in tomato. Chemosphere. 90, 2645-2653.

Ali, B., Hasan, S.A., Hayat, S., Hayat, Q., Yadav, S., Fariduddin, Q., Ahmad, A. 2008. A role for brassinosteroids in the amelioration of aluminium stress through antioxidant system in mung bean (Vigna radiata L. Wilczek). Environ. Exp. Bot. 62, 153-159.

Athar, H.R., Khan, A., Ashraf, M. 2008. Exogenously applied ascorbic acid alleviates salt-induced oxidative stress in wheat. Environmental and Experimental Botany. 63, 224-231.

Bajguz, A. 2000. Effect of brassinosteroids on nucleic acid and protein content in cultured cell of Chlorella vulgaris. Plant Physiol. Biochem. 38, 209-215.
Chen, Z., Cui, T.A., Zhou, M., Twomey, A., Naidu, B.P., Shabala, S. 2007. Compatible solute accumulation and stress-mitigating effects in barley genotypes contrasting in their salt tolerance. J. Exp. Bot. 58, 4245-4255.

Choudhary, S.P., Yu, J.Q., Yamaguchi-Shinozaki, K., Shinozaki, K., Tran L.S.P. 2012. Benefits of brassinosteroid crosstalk. Trends in Plant Science. 17, 594-605.

Derevyanchuk, M., Litvinovskaya, R., Khripach, V., Martinec, J., Kravets, V. 2015. Effect of 24-epibrassinolide on Arabidopsis thaliana alternative respiratory pathway under salt stress. Acta Physiol. Plant. 37, 215.

Dong, D.F., Li, Y.R., Jiang, L.G. 2008. Effects of Brassinosteroid on photosynthetic characteristics in soybean under aluminum stress. Acta Agron. Sin. $34,1673-1678$.

Dong, Y.J., Wang, Z.L., Zhang, J.W., Liu, S., He, Z.L., He, M.R. 2015. Interaction effects of nitric oxide and salicylic acid in alleviating salt stress of Gossypium hirsutum L. Journal of Soil Science and Plant Nutrition. 15, 561-573.

Dong, Y.J., He, M.R., Wang, Z.L., Chen, W.F., Hou, J., Qiu, X.K., Zhang, J.W. 2016. Effects of new coated release fertilizer on the growth of maize. Journal of Soil Science and Plant Nutrition. 16, 637-649.

Duncan, D.R., Widholm, J.M. 2004. Osmotic induced stimulation of the reduction of the viability dye 2,3,5-triphenyltetrazolium chloride by maize roots and callus cultures. J. Plant Physiol. 161, 397-403.

Egbichi, I., Keyster, M., Jacobs, A., Klein, A., Ludidi, N. 2013. Modulation of antioxidant enzyme activities and metabolites ratios by nitric oxide in short-term salt stressed soybean root nodules. South African Journal of Botany. 88, 326-333. 
Fariduddin, Q., Ahmed, M., Mir, B.A., Yusuf, M., Khan, T. A. 2015. 24-Epibrassinolide mitigates the adverse effects of manganese induced toxicity through improved antioxidant system and photosynthetic attributes in Brassica juncea. Environ. Sci. Pollut. Res. 22, 11349-11359.

Frédéric, G., Duby, G., Stedingk, E.V., Zhao, R.M., Morsomme, P., Boutry, M. 2007. Expression of a constitutively activated plasma membrane $\mathrm{H}+-$ ATPase alters plant development and increases salt tolerance. Plant Physiol. 144, 1763-1776.

Geissler, N., Hussin, S., Koyro, H.W. 2009. Interactive effects of $\mathrm{NaCl}$ salinity and elevated atmospheric $\mathrm{CO}_{2}$ concentration on growth, photosynthesis, water relations and chemical composition of the potential cash crop halophyte Aster tripolium L. Environ. Exp. Bot. 65, 220-231.

Hayat, S., Hasan, S.A., Hayat, Q., Ahmad, A. 2010. Brassinosteroids protect Lycopersicon esculentum from cadmium toxicity applied as shotgun approach. Protoplasma. 239, 3-1.

Hu, W.H., Wu, Y., Zeng, J.Z., He, L., Zeng, Q.M. 2010. Chill-induced inhibition of photosynthesis was alleviated by 24-epibrassinolide pretreatment in cucumber during chilling and subsequent recovery. Photosynthetica. 48, 537-544.

Hua, W.H., Yan, X.H., Xiao, Y.A., Zeng, J.J., Qi, H.J., Ogweno, J.O. 2013. 24-Epibrassinosteroid alleviate drought-induced inhibition of photosynthesis in Capsicum annuum. Scientia Horticulturae. 150, 232-237.

Hussain, M.I., Lyra, D.A., Nikos, M., Farooq, Ahmad, N. 2016. Salt and drought stresses in safflower: A Review. Agronomy for Sustainable Development. 36, 1-31.

Karlidag, H., Yildirim, E., Turan, M. 2011. Role of 24-epibrassinolide in mitigating the adverse effects of salt stress on stomatal conductance, membrane permeability, and leaf water content, ionic composition in salt stressed strawberry (Fragaria $\times$ ananassa). Scientia Horticulturae. 130, 133-140.
Khripach, V., Zhabinskii, V., Groot, A. 2000. Twenty years of brassinosteroids: Steroidal plant hormones warrant better crops for the XXI century. Ann. Bot. 86, 441-447.

Li, G.Z., Peng, X.Q., Wei, L.T., Kang, G.Z. 2013. Salicylic acid increases the contents of glutathione and ascorbate and temporally regulates the related gene expression in salt-stressed wheat seedlings. Gene. 529, 321-325.

Li, Q.Y., Niu, H.B., Yin, J., Wang, M.B., Shao, H.B., Deng, D.Z., Chen, X.X., Ren, J.P., Li, Y.C. 2008. Protective role of exogenous nitric oxide against oxidative-stress induced by salt stress in barley (Hordeum vulgare). Colloids and Surfaces Biointerfaces. 65, 220-225.

López-Gómez, M., Hidalgocastellanos, J., Lluch, C., Herreracervera, J.A. 2016. 24-Epibrassinolide ameliorates salt stress effects in the symbiosis Medicago truncatula-Sinorhizobium meliloti and regulates the nodulation in cross-talk with polyamines. Plant Physiology \& Biochemistry. 08, 212-221.

Mazorra Morales, L.M., Senn, M.E., Gergoff Grozeff, G.E., Fanello, D.D., Carrión, C.A., Núñez, M., Bishop, G.J., Bartoli, C.G. 2014. Impact of brassinosteroids and ethylene on ascorbic acid accumulation in tomato leaves. Plant Physiol. Biochem. 74, 315-322.

Rady, M.M. 2011. Effect of 24-epibrassinolide on growth, yield, antioxidant system and cadmium content of bean (Phaseolus vulgaris L.) plants under salinity and cadmium stress. Scientia Horticulturae. 129, 232-237.

Roy, S., Negrao, S., Tester, M. 2014.Salt resistant crop plants. Current Opinion in Biotechnology. 26, 115-124.

Sharma, I., Ching, E., Saini, S., Bhardwaj, R., Pati, P.K. 2013. Exogenous application of brassinosteroid offers tolerance to salinity by altering stress responses in rice variety Pusa Basmati-1. Plant Physiol. Biochem. 69, 17-26. 
Simaei, M., Khavarinejada, R.A., Saadatmanda, S., Bernardb, F., Fahimia, H. 2011. Interactive effects of salicylic acid and nitric oxide on soybean plants under $\mathrm{NaCl}$ salinity. Russ. J. Plant Physiol. 58, 783-790.

Song, Y.L., Dong, Y.J., Tian, X.Y., Kong, J., Bai, X.Y., Xu, L.L., He, Z.L. 2016. Role of foliar application of 24-epibrassinolide in response of peanut seedlings to iron deficiency. Biologia Plantarum. 60, 329-342.

Tian, X.Y., He, M.R., Wang, Z.L., Zhang, J.W., Song, Y.L., He, Z.L., Dong, Y.J. 2015. Application of nitric oxide and calcium nitrate enhances tolerance of wheat seedlings to salt stress. Plant Growth Regul. 77, 343-356.

Wang, M., Jiang, W., Yu, H. 2010. Effects of exogenous epibrassinolide on photosynthetic characteristics in tomato (Lycopersicon esculentum Mill) seedlings under weak light stress. J. Agric. Food Chem. 58, 3642-3645.
Wang, W.W., Bai, X.Y., Dong, Y.J., Chen, W.F., Song, Y.L., Tian, X.Y. 2016. Effects of application of exogenous NO on the physiological characteristics of perennial ryegrass grown in $\mathrm{Cd}$ contaminated soil. Journal of Soil Science and Plant Nutrition. 16, 731-744.

Zhang, Y.P., Zhu, X.H., Ding, H.D., Yang, S.J., Chen, Y.Y. 2013. Foliar application of 24-epibrassinolide alleviates high-temperature-induced inhibition of photosynthesis in seedlings of two melon cultivars. Photosynthetica. 51, 341-349.

Zheng, Q.S., Liu, J.L., Liu, R., Wu, H., Jiang, C.Q., Wang, C.H., Guan, Y.X. 2016. Temporal and spatial distributions of sodium and polyamines regulated by brassinosteroids in enhancing tomato salt resistance. Plant Soil. 400, 147-164. 